\title{
PENGARUH PERMAINAN KAREKI TERHADAP HASIL BELAJAR SISWA PADA MATERI IKATAN ION DI SMA ISLAM RAUDHATUL JANNAH PAYAKUMBUH
}

\author{
Yani Pinta 1 \\ ${ }^{1}$ Sekolah Menengah Atas (SMA) Islam Raudhatul Jannah, \\ Jl. Jl. Prof Hamka, Kaning Bukit, Payakumbuh 26215, Indonesia \\ e-mail: yanipinta012@gmail.com
}

\begin{abstract}
ABSTRAK
Rendahnya nilai mata pelajaran kimia siswa disebabkan metode yang digunakan guru belum membuat siswa aktif, sehingga berpengaruh terhadap hasil belajarnya. Penelitian ini bertujuan untuk mengetahui pengaruh permainan Kareki (kartu remi kimia) terhadap hasil belajar siswa kelas X pada materi ikatan ion. Penelitian eksperimen ini dilakukan dengan rancangan penelitian the posttest only control group design. Populasinya siswa kelas X tahun pelajaran 2015/2016 dan sampel sebanyak 2 kelas XA dan XB. Berdasarkan hasil analisis data dengan uji-t taraf kepercayaan $95 \%(\alpha=0,05)$, maka diperoleh thitung $=1,81$ $>1,68=t_{\text {tabel, }}$ berarti hipotesis diterima. Sehingga, dapat disimpulkan terdapat pengaruh positif permainan Kareki terhadap hasil belajar Kimia siswa kelas $X$ pada materi ikatan ion di SMA Islam Raudhatul Jannah Payakumbuh.
\end{abstract}

Kata Kunci : Kartu Remi Kimia, Kareki, hasil belajar, ikatan ion.

\begin{abstract}
The low score of students in chemistry subject is caused by the teaching methods used by teachers that still can not make students active, so that it influences the learning outcomes. This study aims to determine the effect of Kareki (chemistry playing cards) game to the learning outcomes of students in grade $X$ on ionic bond concept. This experimental study was conducted by the posttest only control group research design. The population was the students of grade $X$ in the academic year 2015/2016 and the sample was two classes, XA and XB. Based on the results of data analysis using t-test level of 95\% $(\alpha=$ $0.05)$, $t_{\text {calculated }}=1.81>1.68=t_{\text {table, }}$ means that the hypothesis is accepted. Thus, we can conclude there is a positive influence from Kareki game on chemistry learning outcomes of students grade X in ionic bonding concept in SMA Islam Raudhatul Jannah Payakumbuh.
\end{abstract}

Keywords : chemistry playing cards, kareki, learning outcomes, ionic bonding.

DOI: http://dx.doi.org/10.15575/jta.v1i2.1237 


\section{PENDAHULUAN}

Permendiknas Nomor 16 Tahun 2007 menyebutkan guru profesional harus memiliki kompetensi pedagogik, kepribadian, sosial, dan kompetensi profesional. Kompetensi profesional berkaitan dengan kemampuan menguasai materi, struktur, konsep, dan pola pikir keilmuan yang mendukung dalam menyajikan mata pelajaran yang diampunya. Mengacu pada kompetensi tersebut, guru diharapkan mampu mengembangkan keprofesionalan secara berkelanjutan dengan melakukan tindakan reflektif, termasuk bisa memanfaatkan teknologi informasi dan komunikasi (IT) untuk berkomunikasi dan mengembangkan diri. KTSP menuntut guru yang berkualitas dan professional untuk melakukan kerjasama dalam rangka meningkatkan kualitas pendidikan dan karakter siswa. Salah satu kompetensi guru yang sangat mendukung adalah memilih media yang dibutuhkan dalam mengajarkan suatu materi pelajaran.

Pada proses belajar kimia, pengajaran keterampilan proses yang salah satunya adalah belajar dengan berbuat (learning by doing) perlu untuk ditekankan. Pengajaran keterampilan proses diperlukan karena bidang studi kimia merupakan bidang studi yang tidak hanya menuntut hafalan dan pengetahuan saja akan tetapi juga keterampilan mental. Indikasi ini dapat dilihat dari dasar-dasar ilmu kimia yang berhubungan dengan lingkungan hidup, pemahaman cara kerja, pengamatan, pengembangan kemandirian, dan kerja kelompok.

Berdasarkan observasi awal melalui wawancara beberapa siswa SMA Islam Raudhatul Jannah Payakumbuh, siswa menuturkan bahwa pembelajaran kimia sering membosankan dan menjenuhkan. Hal ini disebabkan karena sebagian besar metode atau media yang digunakan guru dalam pembelajaran kimia masih konvensional (metode ceramah) dan berakibat pada rendahnya minat dan motivasi siswa dalam belajar kimia. Hal ini terlihat pada rata-rata nilai mata pelajaran Kimia di kelas $\mathrm{X}$ pada dua tahun terakhir yang nilai ketuntasan masih di bawah kriteria ketuntasan minimal (KKM). Hal ini dapat dilihat pada tabel 1 .

Kesulitan siswa dalam mempelajari suatu materi sangat tergantung pada cara guru mengajar. Guru dapat mengubah rasa takut siswa terhadap pelajaran kimia dengan menyampaikan materi pelajaran melalui cara yang menarik, sehingga akan menjadikan siswa merasa senang dan kemudian mampu mendorong siswa aktif proses belajar mengajar. Belajar efektif hanya terjadi dalam suasana yang menyenangkan dengan kegiatan yang mengaktifkan semua kecerdasan siswa, sehingga pembelajaran harus dikemas secara menarik serta dalam proses pembelajarannya juga harus melibatkan keaktifan siswa.

Tabel 1. Rata-nata nilai semester I Kimia kelas $\mathbf{X}$

\begin{tabular}{|c|c|c|c|}
\hline $\begin{array}{c}\text { Tahun } \\
\text { Ajaran }\end{array}$ & KKM & $\begin{array}{c}\text { Rata-Rata } \\
\text { Nilai Kimia }\end{array}$ & Ketuntasan \\
\hline $2014 / 2015$ & 75 & 74,9 & $71 \%$ \\
\hline $2013 / 2014$ & 70 & 71 & $69 \%$ \\
\hline
\end{tabular}

Sistem pembelajaran yang memberi kesempatan kepada siswa untuk aktif melakukan kegiatan belajar mengajar ini akan menyebabkan siswa terdorong untuk mempelajari suatu materi pembelajaran, sehingga apa yang diperoleh siswa dari proses belajar itu akan lebih bermakna. Salah satu yang dapat digunakan untuk menyampaikan suatu materi pelajaran adalah permainan Kareki.

Jurnal Tadris Kimiya 1, 2 (Desember 2016): 79-83 
Permainan Kareki adalah permainan dengan menggunakan kartu dalam pembelajaran kimia, sehingga disebut Kareki (Kartu Remi Kimia). Kareki dibuat oleh peneliti sendiri. Permainan Kareki dapat diterapkan pada materi ikatan ion di Kelas X Semester I. Materi ikatan ion adalah materi yang memuat ikatan antara atom-atom untuk mencapai kestabilan. Ikatan ini terbentuk apabila terjadi serah terima elektron antara atom satu dengan atom yang lain. Materi ini sulit dipraktikumkan di laboratorium kimia, karena terbentuknya ion positif dan ion negatif tidak bisa dilihat dengan mata. Apabila materi ini disampaikan dengan media yang tidak tepat, maka materi ini akan terasa sulit oleh siswa. Permainan Kareki dapat membantu siswa untuk memahami materi ikatan ion dengan baik.

\section{METODOLOGI}

Jenis penelitian ini adalah penelitian kuantitatif dengan menggunakan metode eksperimen dengan rancangan posttest only control group design. Dalam penelitian ini, populasi yang diambil adalah jumlah seluruh siswa kelas $X$ tahun pelajaran 2015/2016 dengan sampel sebanyak 2 kelas yang terdiri dari 41 orang siswa. Kelas dibagi secara acak menjadi kelas eksperimen dan kelas kontrol. Analisis uji hipotesis dilakukan dengan menggunakan uji kesamaan dua rata-rata dengan Uji-T ( $T$ test), taraf kepercayaan 95\% $(\alpha=0,05)$.

\section{HASIL DAN PEMBAHASAN}

Setelah dilakukan penelitian terhadap materi ikatan ion sebanyak $5 \times$ pertemuan pada kedua kelas sampel, maka diperoleh data hasil belajar siswa. Data tersebut diperoleh dari tes akhir pada kegiatan penelitian. Pada tes akhir digunakan 20 butir soal objektif. Pada kelas eksperimen tes akhir diikuti oleh 21 orang siswa, sedangkan pada kelas kontrol diikuti 20 orang siswa.
Berdasarkan hasil analisis jawaban siswa pada kegiatan tes akhir, diperoleh data hasil belajar siswa yang dapat dilihat pada Lampiran 7 halaman 72. Dari data tersebut, peneliti melakukan analisa data pada kedua kelas sampel. Secara ringkas hasil analisis data tersebut disajikan pada tabel 2.

Tabel 2. Perhitungan rata-rata varians test dan simpangan baku.

\begin{tabular}{|l|c|c|c|c|}
\hline \multicolumn{1}{|c|}{ Kelas } & $\mathbf{n}$ & $\overline{\mathbf{X}}$ & $\mathbf{S}^{2}$ & $\mathbf{S}$ \\
\hline Eksperimen & 21 & 82,38 & 131,55 & 11,42 \\
\hline Kontrol & 20 & 76,50 & 89,74 & 9,47 \\
\hline
\end{tabular}

Dari data pada tabel 2 tampak bahwa hasil belajar Kimia siswa pada kelas eksperimen (kelas yang diberi perlakuan) lebih tinggi dari pada kelas kontrol (kelas yang tidak diberi perlakuan). Nilai rata-rata pada kelas eksperimen adalah 82,38 sedangkan pada kelas kontrol adalah 76,50.

Berdasarkan hasil uji normalitas dan uji homogenitas, diperoleh sampel berdistribusi normal dan homogen. Dari data tersebut, peneliti melakukan analisa data pada kedua kelas sampel. Secara ringkas hasil analisis data tersebut disajikan pada tabel 3 berikut.

Tabel 3 Hasil uji hipotesis kelas sampel

\begin{tabular}{|l|c|c|c|c|c|}
\hline \multicolumn{1}{|c|}{ Kelas } & $\mathbf{n}$ & $\mathbf{D k}$ & $\boldsymbol{\alpha}$ & $\mathbf{t}_{\text {hitung }}$ & $\mathbf{t}_{\text {tabel }}$ \\
\hline Eksperimen & 21 & \multirow{2}{*}{39} & 0,05 & 1,81 & 1,68 \\
\cline { 1 - 2 } Kontrol & 20 & & & & \\
\hline
\end{tabular}

Dari hasil uji hipotesis diperoleh harga $t_{\text {hitung }}$ $=1,81>t_{\text {tabel }}=1,68$ yang berarti hipotesis alternatif diterima. Artinya permainan Kareki berpengaruh terhadap hasil belajar Kimia siswa kelas X pada materi ikatan ion di SMA Islam Raudhatul Jannah Payakumbuh. 
Persentase ketuntasan kelas eksperimen bernilai lebih tinggi, yaitu sebesar $85,7 \%$, dibandingkan persentase ketuntasan kelas kontrol, yaitu sebesar $70 \%$ Hal ini menandakan bahwa terdapat pengaruh positif pada permainan Kareki (Kartu Remi Kimia) terhadap hasil belajar Kimia siswa kelas X pada materi ikatan ion di SMA Islam Raudhatul Jannah Payakumbuh. Pembelajaran dengan permainan Kareki telah berdampak positif terhadap hasil belajar siswa, sebab dalam pembelajaran ini siswa mendapat bantuan dari teman satu timnya sehingga siswa lebih berani bertanya apa saja yang belum siswa pahami dan aktif dalam menjalankan diskusi. Karena pada kenyataannya banyak siswa yang ketika pembelajaran berlangsung takut untuk bertanya.

Permainan Kareki ini sangat menarik bagi siswa dan membantu siswa memahami konsep ikatan ion. Adapun konsep kognitif yang didapat siswa antara lain ion adalah atom/senyawa yang bermuata; ion ada yang bermuatan positif (kation) dan bermuatan negatif (anion, kation diwakili oleh kartu remi yang berwarna hitam dan kartu merah mewakili anion); letak golongan atom berada pada tepi kiri dan bersebrangan pada kartu remi kimia, yang membantu siswa mengenali atom dan muatan dari atom tersebut; sistem periodik unsur, dibagian belakang kartu remi kimia ada sistem periodik unsur yang membantu siswa memahami sistem periodik unsur, golongan dan perioda; ikatan ion mudah dipahami, Ikatan ion adalah ikatan antara ion positif dan ion negatif, kartu hitam dan kartu merah; dan membantu siswa menghafal ion-ion, karena setiap pelemparan kartu siswa harus melafalkan kartu yang dikeluarkan.

Permainan kareki mampu mengembangkan aspek afektif siswa. Siswa berlomba-lomba untuk menjadi pemenang. Siswa saling menyemangati dalam kelompoknya dan saling berdiskusi dengan teman dalam satu kelompok untuk menjadi pemenang kelas.
Interaksi dalam kelompok ini mengembangkan sikap kerjasama, toleran, empati dan bertanggung jawab.

Aspek psikomotor siswa terlihat dalam permainan Kareki. Siswa aktif dan cekatan dalam memainkan kartu reminya. Pada pembelajaran dengan memanfaatkan permainan Kareki, guru dapat menerapkan penilaian keaktifan siswa. Semua anggota kelompok harus ikut aktif dalam mencocokan kartu yang telah dibagikan. Begitu pula saat diskusi dalam permainan antarkelompok, setiap siswa dapat aktif bertanya, menjawab, dan menyanggah jawaban dari temannya. Dari pengamatan peneliti, hampir semua siswa aktif dan membagi tugas dengan baik agar dapat memperoleh skor tertinggi dan menjadi pemenang di kelas. Kegiatan diskusi yang dilakukan dapat berfungsi sebagai alternatif untuk menjadikan siswa aktif. Hal ini sangat mendukung dalam pemahaman konsep siswa tentang ikatan kimia. Kartu remi kimia mampu memenuhi 3 ranah yang dituntut dalam pembelajaran yaitu aspek kognitif, afektif dan psikomotor siswa.

Kemudian, latihan yang diberikan guru dapat dijawab dengan baik oleh setiap siswa. Hal ini mengakibatkan hasil belajar siswa sesuai dengan yang diharapkan. Hasil belajar memiliki peran penting dalam proses belajar mengajar. Penilaian di dalam hasil belajar dapat memberikan informasi kepada guru mengenai kemajuan siswa dalam upaya mencapai tujuan proses belajar mengajar sampai sejauh mana kemajuan ilmu pengetahuan yang telah mereka kuasai. Allah berfirman dalam AlQur'an yang artinya :

"Sesungguhnya Allah tidak merubah keadaan sesuatu kaum sehingga mereka merubah keadaan yang ada pada diri mereka sendiri"(Qs. Ar-Ra'du : 11).

Dengan media kartu remi, siswa dapat belajar dengan nyaman dan menyenangkan, yang terlihat pada keaktifan siswa dalam proses belajar mengajar. Manfaat dari media 
kartu remi ini adalah menarik perhatian siswa, memahami konsep ikatan ion dan menumbuhkan partisipasi aktif belajar siswa. PermainanKareki sangat menarik bagi siswa.

\section{KESIMPULAN}

Berdasarkan hasil pengujian hipotesis didapatkan bahwa $t_{\text {hitung }}=1,81>1,68=t_{\text {tabel }}$

\section{DAFTAR PUSTAKA}

Fathurrohman, Pupuh dan Sobry Sutikno. 2007. Strategi Belajar Mengajar. Bandung: PT. Refika Aditama.

Http://isjd.pdii.Lipi.Go.Id/Admin/Jurnal/4209 8993/pdf/Jurnal Inovasi Pendidikan Kimia,Vol.4,No.1,2010.

Lie, Anita (2002). Cooperative Learning Mempraktekkan Cooperative Learning di Ruang Kelas. Jakarta: PT Grasindo

Lubis, Syahron. 2011. Metodologi Penelitian Pendidikan. Padang:Sukabina Press.

Lufri, dkk. 2007. Strategi Pembelajaran Biologi. Padang: Universitas Negeri Padang.

Panen, Paulina, dkk. 2004. Belajar dan Pembelajaran /. Jakarta: Universitas Terbuka.

Resi Pratiwi, 2009,"Efektivitas Media ChemoEdutaiment Domino Ikatan Kimia sebagai Aplikasi Pendekatan Pakem yang mana hipotesis penelitian dapat diterima. Berdasarkan hasil penelitian dan pembahasan, maka dapat disimpulkan bahwa permainan Kareki dap mempengaruhi hasil belajar Kimia sisv kelas $X$ pada materi Ikatan Ion di SMA Islam Raudhatul Jannah Payakumbuh ke arah yang lebih baik dan hasil belajar siswa dapat mencapai kriteria ketuntasan minimal (KKM).

terhadap Hasil Belajar Kimia SMA", Semarang: FMIPA Unnes.

Robert E, Slavin, 2005, Media yang Menarik dan Menyenangkan; Teori, Riset dan Praktek, Bandung: Remaja Rosda Karya.

Siti Khomsatun, 2010," Penggunaan Media Pembelajaran Kartu Domino pada Materi Bilangan Pecahan menggunakan Model Pembelajaran Realistic Mathematic Education", Semarang: FMIPA Unnes.

Sudjana. 2005. Metoda Statistika. Bandung: Tarsito.

Sudjana, Nana. 2010. Dasar-Dasar Proses Belajar Mengajar. Bandung: Sinar Baru Algesindo.

Sudjana, Nana dan Ahmad Rivai. 2010. Media Pengajaran. Bandung: Sinar Baru Algensindo.

Thobroni, Muhammad dan Arif Mustafa. 2011. Belajar dan Pembelajaran. Jogjakarta: AR-Ruzz Media. 